\title{
THE LIFE AND TIMES OF THE GENUINE LINK
}

\author{
Rayner Thwaites*
}

\begin{abstract}
The genuine link principle has become a standard-bearer for the view that citizenship is, or should be, substantive, in the sense that it is conditioned on the existence of certain "social facts". As such, it has become a source of inspiration in citizenship theory. It is seen to provide a benevolent framework for thinking about citizenship status. Against the tendency to treat "genuine link" as a guiding principle, I argue that it carries within it fundamental problems. These problems have been known for a long time. In particular, they were prefigured in dissents in the decision that introduced the principle, namely the International Court of Justice's (ICJ) decision in Nottebohm, delivered in 1955, in the initial academic legal commentary on that decision, and in the doctrine's subsequent legal reception. Drawing on these sources I argue that genuine link, as employed in Nottebohm, has in doctrinal terms been confined to a historical footnote. In a second strand of the argument, I develop the problems that attend using the genuine link as a beacon, both in theory and practice.
\end{abstract}

\section{INTRODUCTION}

The genuine link principle has become a standard-bearer for the view that citizenship is, or should be, substantive, in the sense that it is conditioned on the existence of certain "social facts". ${ }^{1}$ As such, it has become a source of inspiration in citizenship theory. ${ }^{2}$ It is seen to provide a benevolent

* Senior Lecturer, University of Sydney Law School. My thanks to the participants in the staff seminar at the Faculty of Law, University of Alberta, 20 November 2017; "Dynamic Evolution of International Law", Victoria University of Wellington, 15-16 December 2017; and "The New Citizenship: Law, Legal Status and Belonging in the 21st Century", University of Sydney, 15-16 March 2018. Thanks also to Elisa Arcioni, Jutta Brunnée, David Dyzenhaus, Helen Irving, Karen Knop, Ellen Moore, Jacqueline Mowbray, Jo Shaw, Kevin Stack and the anonymous peer reviewer for written comments or discussion at different points. My thanks to Ellen Moore for her superb research assistance.

1 The genuine link principle is also commonly referred to as the "genuine connection" requirement. Where appropriate, I refer to the genuine link as a principle, a doctrine and a test. For the purpose of this article, the congruence between the concepts of nationality and citizenship is such that the terms are used interchangeably.

2 In Part IV I analyse a prominent case study, the use made of the genuine link principle in Ayelet Shachar The Birthright Lottery: Citizenship and Global Inequality (Harvard University Press, Cambridge (Mass), 2009) at ch 6 . 
framework for thinking about citizenship status. Against the tendency to treat "genuine link" as a guiding principle, I argue that it carries within it fundamental problems. These problems have been known for a long time. In particular, they were prefigured in dissents in the decision that introduced the principle, namely the International Court of Justice's (ICJ) decision in Nottebohm, ${ }^{3}$ delivered in 1955, in the initial academic legal commentary on that decision, and in the doctrine's subsequent legal reception. Drawing on these sources I argue that genuine link, as employed in Nottebohm, has in doctrinal terms been confined to a historical footnote. ${ }^{4}$ In a second strand of the argument, I develop the problems that attend using the genuine link as a beacon, both in theory and practice. ${ }^{5}$

The genuine link principle was introduced in Nottebohm and is encapsulated in the following passage from the majority judgment: ${ }^{6}$

... nationality is a legal bond having as its basis a social fact of attachment, a genuine connection of existence, interests and sentiments, together with the existence of reciprocal rights and duties. It may be said to constitute the juridical expression of the fact that the individual upon whom it is conferred, either directly by the law or as a result of an act of the authorities, is in fact more closely connected with the population of the State conferring nationality than with that of any other State.

To understand the nature of the principle and its implications we need context, and start by returning to the decision that introduced it. Nottebohm concerned the admissibility of a claim to diplomatic protection by Liechtenstein against Guatemala in respect of injuries to a Liechtenstein national, Mr Friedrich Nottebohm. To adopt the International Law Commission's definition, contained in Article 1 of its Draft Articles on Diplomatic Protection: ${ }^{7}$

3 Nottebohm (Liechtenstein v Guatemala) [1955] ICJ Rep 4

$4 \quad$ I arrive at the same conclusion as Audrey Macklin in "Is it Time to Retire Nottebohm?" (2017) 111 AJIL Unbound 492.

5 In its scope, this article is confined to the genuine link requirement as it relates to natural human persons and references to persons or individuals are to be understood accordingly. The influence of the genuine link requirement has radiated outward: Case No A/18 (Iran v United States) (1984) 75 ILR 175 at 192. For introductions to its usage with respect to flag ships and corporations see respectively Doris König Max Planck Encyclopedia of Public International Law (2009, online ed) Flag of Ships; and Manuel Casas "Nationalities of Convenience, Personal Jurisdiction, and Access to Investor-State Dispute Settlement" (2016) 49 NYU J Intl Law \& Pol 63.

$6 \quad$ Nottebohm, above n 3, at 23.

7 Report of the International Law Commission on the work of its fifty-eighth session [2006] vol 2, pt 2 YILC 1 [ILC 2006 Report, Yearbook] at [49], "Text of the draft articles on diplomatic protection", art 1. In Ahmadou Sadio Diallo (Republic of Guinea v Democratic Republic of the Congo) (Preliminary Objections) [2007] ICJ Rep 582 at 599 the International Court of Justice confirmed that the definition in art 1 of the Draft Articles reflects international customary law. 
... diplomatic protection consists of resort to diplomatic action or other means of peaceful settlement by

a State adopting in its own right the cause of its national in respect of an injury to that national arising

from an internationally wrongful act of another State ...

Diplomatic protection is a means by which a state can bring a claim at international law on behalf of one of its nationals. In Nottebohm it was agreed between the parties and noted by the Court at the outset of its reasoning that "it is the bond of nationality between the State and the individual which alone confers upon the State the right of diplomatic protection". ${ }^{8}$ Nottebohm was born a German citizen in 1881. He acquired Liechtenstein citizenship in 1939, losing his German citizenship in the process. He was a long-time resident, but not a citizen, of Guatemala, taking up residence there in 1905. The substantive claim pursued through diplomatic protection was compensation from Guatemala for actions that took place in 1943 and following, his "unjustified detention, internment, expulsion, and subsequent exclusion, from Guatemala ... and by the sequestration and confiscation of his property". 9

The majority held that to be eligible to bring a claim for diplomatic protection on Nottebohm's behalf, Liechtenstein needed to establish: (a) that Nottebohm was a national of Liechtenstein under its law; and (b) that he had a genuine connection with Liechtenstein. ${ }^{10}$ Guatemala's objection to the admissibility of Liechtenstein's claim succeeded at the second step. The majority found that Nottebohm did not have a "genuine connection" with Liechtenstein at the time of naturalisation, ${ }^{11}$ and accordingly that Liechtenstein's claim to diplomatic protection on his behalf was inadmissible at international law. In addition to the majority judgment there were three dissents, all of which dissented both as to the existence of the "genuine link" concept in law and as to the result. ${ }^{12}$ The reasoning and commentary of Judge Read's dissent is of particular importance to my argument. ${ }^{13}$

8 Nottebohm, above n 3, at 13, quoting from Panevezys-Saldutiskis Railway (Estonia v Lithuania) (Judgment) (1939) PCIJ (series A/B) No 76 at 16.

9 Mervyn Jones "The Nottebohm Case" (1956) 5 ICLQ 230 at 231. The relevant passage from Liechtenstein's memorial is quoted in Nottebohm, above n 3, at 6-7.

10 Nottebohm, above n 3, at 23. See also HF van Panhuys The Role of Nationality in International Law: An Outline (AW Sijthoff, Leiden, 1959) at 97.

11 Nottebohm, above n 3, at 24-26. There has been a long-running debate, beginning with a difference between the majority and dissents in Nottebohm, as to the correctness of the majority's decision to treat the time of naturalisation as the "critical date" on which Nottebohm's "genuine link" with Liechtenstein fell to be established. For a sustained discussion of this issue see LFE Goldie "The Critical Date" (1963) 12 ICLQ 1251 at $1268-1273$.

12 Compare Robert Sloane "Breaking the Genuine Link: The Contemporary International Legal Regulation of Nationality" (2009) 50 Harv Intl LJ 1 at 4 and generally 11-24. Sloane argues that the genuine connection test was dicta and that the basis of the Court's decision was a tacit application of the doctrine of abuse of right.

13 The other dissents were Judge Klaestad and Judge Guggenheim (ad hoc). 
In terms of the basis of nationality law and the relationship between international and domestic law in this area, Nottebohm itself is regularly cited as authority for the proposition that: ${ }^{14}$

... it is for every sovereign State, to settle by its own legislation the rules relating to the acquisition of its nationality, and to confer that nationality by naturalization granted by its own organs in accordance with that legislation.

While it is for each state to determine the grant of its own nationality, this is not to say that a state's determination is to be accepted internationally without question. Article 1 of the Convention on Certain Questions Relating to the Conflict of Nationality Laws 1930 states: ${ }^{15}$

It is for each State to determine under its law who are its nationals. This law shall be recognised by other

States in so far as it is consistent with international conventions, international custom, and the principles

of law generally recognised with regard to nationality.

Article 1 is generally treated as a statement of customary international law and appears to have been so treated by the majority in Nottebohm. ${ }^{16}$

In Nottebohm, the majority went out of its way to stress that it was not impugning the validity of Liechtenstein's grant of citizenship to Nottebohm as a matter of domestic law. ${ }^{17}$ It was only denying recognition to that grant of citizenship as a matter of international law, insofar as that citizenship was being used to ground a claim for diplomatic protection as against Guatemala. ${ }^{18}$ A consistent set of criticisms of "genuine link", first voiced in the dissents in Nottebohm, attaches to the majority's position that non-recognition for the purpose of diplomatic protection would leave his citizenship otherwise unaffected. ${ }^{19}$ This set of criticisms objects that it is incoherent to refuse recognition to Nottebohm's citizenship with respect to one core attribute of citizenship (diplomatic protection) while leaving untouched, for example, Liechtenstein's obligation to accept him as a national if deported there.

In Part II, the discussion of the "genuine link" is anchored in the circumstances of Nottebohm and the majority reasoning that gave us the principle. The initial legal response to the reasoning in

14 Nottebohm, above n 3, at 20, quoted, for example, by the High Court of Australia in Re Canavan [2017] HCA 45, (2017) 91 ALJR 1209 at [38]. See also Sykes v Cleary [1992] HCA 60, (1992) 176 CLR 77 at 106 per Mason CJ, Toohey and McHugh JJ.

15 Convention on Certain Questions Relating to the Conflict of Nationality Law 179 LNTS 89 (adopted 12 April 1930, entered into force 1 July 1937), art 1.

16 Nottebohm, above n 3, at 23.

17 At $20-21$.

18 At 17 and $20-21$.

19 See for example Nottebohm, above n 3, at 46-48 per Judge Read dissenting; Josef L Kunz "The Nottebohm Judgement (Second Phase)" (1960) 54 AJIL 536 at 547-548; and Macklin, above n 4, at 495-496. 
Nottebohm, and particularly the genuine link principle, was broadly critical, with academic commentary more inclined to side with, develop and supplement the criticisms contained in the dissents. This critical response was not confined to scholarship. It also characterised the reception of the genuine link doctrine in subsequent legal decisions and fora as outlined in Part III. One concern was that the genuine link doctrine, with its attendant problems, would burst the bounds of diplomatic protection and be applied as a principle of nationality more generally. This prospect has eventuated within citizenship theory, as developed in the illustrative case study of a related principle proposed by Shachar, analysed in Part IV. The use made of the genuine link principle in citizenship theory forgets the principle's earlier critical reception. In what follows I draw on that earlier critical reception to illustrate the principle's problems.

To better understand the principle, I return to the circumstances of its origin and identify what was distinctive and new with respect to the genuine link in Nottebohm.

\section{REVISITING NOTTEBOHM}

\section{A The Circumstances of the Case}

Mr Friedrich Nottebohm was born in Hamburg, Germany in 1881, acquiring German citizenship at birth. He retained that German citizenship until his acquisition of the citizenship of Liechtenstein. He took up residence in Guatemala in 1905 and continued to have his fixed abode there until 1943. He was partner in, and later head of, the firm Nottebohm Hermanos, which by the 1930s was the second largest coffee producer in Guatemala. ${ }^{20}$

The injuries to Nottebohm that formed the substance of the claim were actions of the Guatemalan government but were largely instigated by the United States, as outlined below. Other aspects of the United States' involvement related to the fact that Nottebohm and his family had assets in the United States. The key events on which the case turned occurred in and around the Second World War, but some of the tensions and issues which emerged at that time were prefigured in the First World War. In that earlier conflict, the Nottebohm family and business interests came under suspicion for their ties to Germany. ${ }^{21}$ The United States government declared Nottebohm Hermanos to be an enemy alien under the Trading with the Enemy Act (TWEA) and seized its property in the United States. ${ }^{22}$ Following the War the family was able to satisfy United States authorities that the company was not an enemy or ally of an enemy within the meaning of the TWEA and the property was released. ${ }^{23}$

20 Cindy G Buys "Nottebohm's Nightmare: Have We Exorcised the Ghosts of WWII Detention Programs or Do They Still Haunt Guantanamo?" (2011) 11 Chicago-Kent JICL 1 at 3.

21 Buys, above n 20, at 3. The actions of the United States government in World War I are referred to by Judge Read in his dissent in Nottebohm, above n 3, at 49.

22 Trading with the Enemy Act 50 USC $\S 5(\mathrm{~b})$.

23 Buys, above n 20, at 3-4. 
In March 1939, on the eve of the outbreak of World War II, Nottebohm travelled from Guatemala to Europe, visiting Hamburg as well as Vaduz in Liechtenstein, where one of his brothers lived. In October that year, a month after the outbreak of World War II, marked by Germany's attack on Poland, ${ }^{24}$ Nottebohm applied for naturalisation as a citizen of Liechtenstein. He requested, and received, dispensation under Liechtenstein nationality law from the standard naturalisation requirement of three years residence, undertaking various financial payments to the Liechtenstein authorities. ${ }^{25} \mathrm{He}$ was naturalised as a national of Liechtenstein that year. On acquiring Liechtenstein nationality he lost his German nationality by operation of the relevant provision of the German Nationality Law of 1913. On becoming a national of Liechtenstein that became his sole nationality.

Nottebohm obtained a visa for Guatemala using his new Liechtenstein passport and used that passport to return to Guatemala in January $1940 .{ }^{26}$ Guatemala officially entered the war against Germany on 11 December $1941 .^{27}$ In October 1943, Nottebohm was summoned by the Guatemalan authorities to be deported to and detained in the United States on the basis that he was an enemy alien. He protested that he was no longer a German citizen, showing police his Liechtenstein passport. The Swiss embassy, acting on behalf of Liechtenstein, protested his deportation to and detention in the United States, but to no effect. ${ }^{28}$

Friedrich Nottebohm was detained in camps in Texas and then North Dakota together with his nephews Kurt and Karl-Heinz. ${ }^{29}$ Friedrich Nottebohm's treatment in the Second World War formed

24 In discussions of Nottebohm, the wartime context has been raised as going to motivation, see in the text accompanying n 40 below. It was also seen, in a more doctrinal vein, as raising legal issues going to enemy alien status: see for example Goldie, above n 11, at 1271-1272.

25 For this reason, Nottebohm is often characterised as a case involving the sale of citizenship: see for example Ayelet Shachar "Citizenship for Sale?" in Ayelet Shachar and others (eds) The Oxford Handbook of Citizenship (Oxford University Press, Oxford, 2017) 789 at 812. As a normative matter, there is considerable debate as to what should follow from this characterisation: see for example Helen Irving "Citizenship for Sale: What's the Objection?" (Legal Studies Research Paper No 18/05, University of Sydney, 2018).

26 On the legal consequences of Guatemala's acceptance of his Liechtenstein passport see Nottebohm, above n 3, at 46-48 per Judge Read dissenting. This passage from Judge Read has featured in parliamentary debate over the United Kingdom's current practice of stripping a British national of his or her citizenship while he or she is travelling on a British passport overseas. For the start of the exchange conducted through Parliament see Guy Goodwin-Gill "Mr Al-Jedda, Deprivation of Citizenship and International Law" (revised draft of a paper presented to a seminar at Middlesex University, 14 February 2014). Referenced and quoted in United Kingdom Joint Committee on Human Rights Legislative Scrutiny: Immigration Bill (second Report) - Twelfth Report of Session 2013-14 (3 March 2014).

27 Some of the debate over Nottebohm has centred on how the law on enemy aliens applied to the facts: see above $n 24$.

28 Buys, above n 20, at 8-9.

29 At 4-5. On Kurt Nottebohm see Stephen Fox America's Invisible Gulag: A Biography of German American Internment \& Exclusion in World War II: Memory and History (Peter Lang, New York, 2000) at 105. Friedrich's nephews were both born in Guatemala and had become Guatemalan citizens. This raises a 
part of a "United States-Latin American detention" programme, involving over 4,000 such deportees. ${ }^{30}$ The United States pressured Latin American countries to identify and turn over to the United States persons of German nationality or ancestry. While the programme originated in national security concerns, assuming those of German background to be Nazi sympathisers, it was maintained even for those subsequently deemed to present little or no security risk, such as the Nottebohms, on the grounds that it benefitted United States economic influence in Latin America. ${ }^{31}$

Nottebohm was released from Fort Lincoln, North Dakota on 22 January 1946, in midwinter. To quote from Buys: ${ }^{32}$

The [United States] government concluded that it had no credible evidence of Nazi sympathies or activities

by Fredrich Nottebohm. A December 1945 Memorandum from the US Embassy in Guatemala states that

"Nottebohm's name does not appear on the Nazi party list believed to be authentic, and there is no reliable

evidence to indicate that he was a member of the party or even a sympathizer of Hitler."

While Friedrich Nottebohm was in detention, a series of 57 legal proceedings were commenced against him in Guatemala, "designed to expropriate, without compensation to him, all of his properties". 33

On release from detention in the United States, Nottebohm travelled to New Orleans and applied for permission to return to Guatemala. Permission was refused and he "was thus prevented from assuming the personal direction of the complex network of litigation". ${ }^{34}$ In summary, as addressed in Judge Read's dissent, Nottebohm was "arrested, forcibly removed to the United States, interned for over two years, and stripped of his Guatemalan property ... without due process of law". ${ }^{35}$

Nottebohm travelled to Liechtenstein instead. Liechtenstein brought a claim for diplomatic protection to the International Court of Justice, arguing that the Guatemalan government's treatment of the person and property of Nottebohm was contrary to international law in the following respects: ${ }^{36}$

secondary issue, for another article, of the treatment Friedrich Nottebohm would have received if he was a Guatemalan citizen and the implications of the answer to that question.

30 Max Paul Friedman Nazis and Good Neighbors: The United States Campaign against the Germans of Latin America in World War II (Cambridge University Press, Cambridge, 2003) at 2.

31 Friedman, above n 30, at 168.

32 Buys, above n 20, at 11-12.

33 Nottebohm, above n 3, at 34 per Judge Read dissenting.

34 At 34 per Judge Read dissenting.

35 Buys, above n 20, at 15. See also Nottebohm, above n 3, at 34-35 per Judge Read dissenting.

36 Jones, above n 9, at 231; and Nottebohm, above n 3, at 6-7. 
(1) by the unjustified detention, internment, expulsion and subsequent exclusion, from Guatemala, of Nottebohm, and by the sequestration and confiscation of his property; and

(2) by its failure to pay full compensation for the unlawful acts complained of.

Guatemala responded in its final submissions by challenging the admissibility of Liechtenstein's claim for diplomatic protection on the bases that Nottebohm had not acquired Liechtenstein nationality as a matter of domestic law; that, in the alternative, his naturalisation was contrary to "generally recognized principles" of international law; and that his nationality had been solicited fraudulently, to evade the consequences of enemy alien status, without any "genuine intention to establishing a durable link" with Liechtenstein. ${ }^{37}$ The decision with which we are concerned, ${ }^{38}$ that of the International Court of Justice delivered on 6 April 1955, was a preliminary decision on the admissibility of Liechtenstein's claim for diplomatic protection, framed by the majority in terms of the admissibility of Liechtenstein's claim at international law "as against Guatemala".

The motivations imputed to Nottebohm in applying for Liechtenstein citizenship are seen to have influenced the majority's decision. These questions of motivation go to the Court's attitude and disposition with regards to the claim, as distinct from the legal relevance expressly assigned to motivation. Weis helpfully summarises factors thought likely to have coloured the majority's decision, including: ${ }^{39}$

Professor Henri Rolin's allusions, in his eloquent pleadings as counsel for Guatemala, that Nottebohm had bought his naturalization; that he had been a member of the Nazi party, and the emphasis on his close business connections with Germany.

Weis also emphasises views in wide circulation as to the ease with which German nationality could be resumed, ${ }^{40}$ supporting a narrative whereby Nottebohm was temporarily relinquishing his German nationality to avoid the consequences of enemy alien status for his commercial interests.

An alternative set of motivations was readily available to the Court at the time of judgment, as most publicly evidenced by the dissents, the most sustained of which is that offered by Judge Read. Judge Read suggests that, rather than concerns about anticipated Guatemalan belligerency, the more likely motivation for Nottebohm's naturalisation was to protect Nottebohm Hermanos' assets in the

37 Nottebohm, above n 3, at 11.

38 This article addresses the 1955 Nottebohm decision of the International Court of Justice, as distinct from an earlier decision in the litigation, Nottebohm (Liechtenstein v Guatemala) [1953] ICJ Rep 111.

39 Paul Weis Nationality and Statelessness in International Law (2nd ed, Sijthoff \& Noordhoff, The Netherlands, 1979) at 179-180.

40 At 179 , and see 79-80. This influence is evident on the face of the majority judgment: see for example Nottebohm, above n 3, at 26. 
United States. ${ }^{41}$ This concern had its source in the United States' conduct in World War I, ${ }^{42}$ mentioned above.

Diplomatic protection was the sole remaining means by which Nottebohm could bring a legal proceeding with respect to the actions of the Guatemalan government regarding his internment, deportation and confiscation of property. If he could not bring a claim for diplomatic protection by way of his citizenship of Liechtenstein, he was effectively stateless for the purpose of diplomatic protection. ${ }^{43}$ The dissents and early critics were inclined to view diplomatic protection as a procedural mechanism whereby an individual could access international justice. ${ }^{44}$ By way of contrast, the majority judgment was seen to favour state interests by imposing "yet a further limitation upon the availability of international justice to the individual as such". 45

\section{B Nottebohm's Distinctive Contribution: a "Restrictive Innovation"}

In this section, I outline both what distinguished the doctrine introduced in Nottebohm from its precursors and how its precursors informed its content. The requirement of "genuine link" introduced in Nottebohm was a "restrictive innovation" in the field of international claims. ${ }^{46}$ More particularly, what was new was the application of the "genuine connection" requirement to a person with only one nationality. ${ }^{47}$ The precedents the Court gave for the genuine connection test were taken from

41 Nottebohm, above n 3, at 48-49 per Judge Read dissenting. In addition to the influence of the United States government on the Guatemalan authorities in World War II, described above, the United States government seized the assets of Nottebohm Hermanos in the United States: Buys, above n 20, at 7-8. See also the later history on the terms of the United States government's settlement with the Nottebohms: Buys, above n 20, at $12-13$.

42 Nottebohm, above n 3, at 49 per Judge Read dissenting. Judge Read had had earlier exposure to wartime expropriation. As legal advisor to the Canadian Department of External Affairs in 1942 he was a forceful, if ultimately unsuccessful, internal critic of the Canadian government's confiscation of the property of Japanese Canadians: see Eric Adams and Jordan Stanger-Ross "Promises of Law: The Unlawful Dispossession of Japanese Canadians" (2017) 54 Osgoode Hall LJ 687.

43 Hans Goldschmidt "Recent Applications of Domestic Nationality Laws by International Tribunals" (1959) 28 Fordham L Rev 689 at 697-698; and Kunz, above n 19, at 543.

44 See for example Jones, above n 9, at 244.

45 Jones, above $\mathrm{n} 9$, at 244 . The distinction is now sometimes expressed as one between a "statist" and individual rights orientation, with the majority in Nottebohm favouring the former and the reasoning of the dissents favouring the latter: see for example Mads Andenas "Reassertion and Transformation: From Fragmentation to Convergence in International Law" (2015) 46 GJIL 685 at 709-711. In the dissents and early criticism of the decision, the emphasis was on a denial of justice as opposed to a denial of individual rights.

46 Jones, above n 9, at 239.

47 Weis, above n 39, at 180. For a defence of the legal reasoning of the Nottebohm majority, including against the charge of "novelty" with respect to the genuine link, see James R Crawford Brownlie's Principles of Public International Law (8th ed, Oxford University Press, Oxford, 2012) at 514-517. 
arbitrations addressed to issues of plural nationality. More particularly, the precedents concerned the doctrine of "effective nationality". ${ }^{48}$ To understand the innovation constituted by the "genuine link" requirement, one needs to appreciate the doctrinal changes wrought by transplanting the "effective nationality" requirement from the plural nationality context to the circumstances of an individual with but one nationality.

The field of operation for the "effective nationality" doctrine was where a national of State A sued State B in circumstances where he or she was also a national of State B. The doctrine of effective nationality is to be understood in its relation to a competing doctrine, the "doctrine of equality". The doctrine of equality held that where an individual had more than one nationality, these nationalities possessed equal weight and none of the states of nationality could bring a claim against the others. ${ }^{49}$ Under the doctrine of equality, a person of plural nationality was precluded from bringing a claim against a state of which he or she was a national. The effective nationality doctrine was a way out of the impasse generated by the doctrine of equality. It held that a state could bring a claim on behalf of a national, as against another state of which he or she was also a national, provided that the claimant state was the state of the person's "real and effective" nationality, meaning the state to which he or she had the stronger factual ties. This was usually the state of domicile. ${ }^{50}$ In its original context, and understood in relation to the competing doctrine of equality, "effective nationality" was a means of enabling a person to bring a claim.

In the plural nationality context, the doctrine of effective nationality allows an assessment of the relative strength of a person's ties, as between his or her countries of nationality. It is a way of managing issues generated by a person's plural nationality, so as to enable a claim that would otherwise be precluded. ${ }^{51}$ The need to assess the relative weight of a person's nationalities is a function of ascribing some weight to both.

In its novel application to Nottebohm, a national of Liechtenstein and nowhere else, the test of "real and effective" nationality ceased to play a role in enabling an individual to make a claim that would otherwise be precluded. It had the opposite effect, serving as a new hurdle to the making of a claim, additional to nationality. The genuine connection requirement introduced in Nottebohm qualified a sole national's ability to exercise a core attribute of his or her nationality status, namely diplomatic protection. It did so on the basis of an assessment of the "genuineness" of his or her ties to the relevant country.

48 Also sometimes referred to as the doctrine of "real and effective nationality".

49 See van Panhuys, above n 10, at 74. See also the commentary of the ILC 2006 Report, Yearbook, above n 7, at [50], commentary to art 7, (2).

50 van Panhuys, above n 10, at 74.

51 Peter Spiro At Home in Two Countries: The Past and Future of Dual Citizenship (New York University Press, New York, 2016) at 64. 
In Nottebohm, a doctrine that had been a means of managing the interaction between two states of nationality changed into something else. It became a doctrine that conditioned a person's ability to exercise his or her only nationality. The exercise of diplomatic protection, grounded in a person's nationality, was now conditioned on an assessment of "social facts" disclosing the presence or absence of a genuine link with the relevant state, absent any need to accommodate or balance the interaction of two nationalities held by a person.

The provenance of the genuine connection test shaped its content and nature. In the Court's judgment in Nottebohm, the factors relevant to genuine connection are elaborated by reference back to the "real and effective nationality" doctrine espoused in the dual nationality context. The Nottebohm majority listed the factors relevant to a finding of "real and effective nationality", and by implication the "genuine link", as follows: 52

... the habitual residence of the individual concerned is an important factor, but there are other factors such as the centre of his interests, his family ties, his participation in public life, attachment shown by him

for a given country and inculcated in his children, etc.

The influence of principles from private international law on the real and effective nationality doctrine is reflected in the primacy accorded to habitual residence. The problem for which the effective nationality doctrine was the solution was how to prioritise between two states of nationality. Concepts from private international law, directed at resolving choice of law issues where an individual was a national of both states under their respective nationality laws, were apt to address this problem.

In the content given to it, the genuine connection test bears the stamp of the private international law concepts that informed the doctrine of real and effective nationality. There is the same concern to locate the state with which one is most closely connected. ${ }^{53}$ It is a concept that is inimical to plural nationality.

\section{GENUINE LINK IN THE CONTEXT OF DIPLOMATIC PROTECTION}

\section{A Genuine Link in its Application to Sole Nationals}

In Part III I argue that the distinctive doctrine introduced in Nottebohm is a dead letter. This position is complicated by the fact that Nottebohm's authority is still called on in support of a different, less problematic, doctrine applicable to plural nationals. I outline where Nottebohm's authority has petered out and conversely the channels into which it has flowed in the area of diplomatic protection.

52 Nottebohm, above n 3, at 22.

53 See the key passage on the genuine link, quoted in text accompanying $\mathrm{n} 6$ above. 
Flegenheimer was a decision of the Italian-United States Conciliation Commission, set up under the Peace Treaty with Italy following the Second World War. ${ }^{54}$ The United States brought a claim against Italy under the Treaty on Mr Flegenheimer's behalf on the basis that he was a United States citizen, with respect to a forced sale at undervalue in $1941 .{ }^{55}$ The Italian government opposed the claim on the basis that Flegenheimer did not hold one of the nationalities required to bring a claim under the Treaty, more particularly that he did not possess United States nationality. The Italian government was successful in this argument.

The Italian government had also advanced an alternative argument, "the theory of effective nationality", according to which, even if Flegenheimer was solely an American national, this nationality had no effect under the Treaty. Italy argued that: ${ }^{56}$

... a nationality is not effective when it confines itself to establishing a nominal link between a State and an individual, and is not supported by a social solidity resulting from a veritable solidarity of rights and duties between the State and its national.

In making this argument the Italian government sought to rely on Nottebohm. ${ }^{57}$ The Commission did not have to address this alternative argument to determine the matter before it. It had already decided against Flegenheimer on the basis that he was not an American national. Nonetheless, the Commission considered the "effective nationality" argument "[i]n the interest of an exhaustive analysis of Albert Flegenheimer's position vis-à-vis the United States". ${ }^{58}$ In its response to the "effective nationality" argument, the Commission stated that "it was doubtful" that Nottebohm established a rule of general international law in its use of the genuine link requirement. ${ }^{59}$

International law texts commonly cite Flegenheimer as the leading authority for the proposition that Nottebohm's genuine connection test should be confined to the facts of the case. ${ }^{60}$ Understood as

54 Flegenheimer Claim (Italian-United States Conciliation Commission) (1958) 25 ILR 91; and Treaty of Peace with Italy 49 UNTS 126 (signed 10 February 1947, entered into force 15 September 1947).

55 The Italian Commission "operated on the basis of diplomatic protection, with states having control of the claim": see Kate Parlett The Individual in the International Legal System: Continuity and Change in International Law (Cambridge University Press, Cambridge, 2011) at 97.

56 Flegenheimer, above n 54, at 147.

57 At 147

58 At 146

59 At 148. "It is perhaps not irrelevant to remark that the third Member of the Commission, Professor SauserHall of Geneva and Neuchatel University, had been counsel for Liechtenstein in the Nottebohm case": Weis, above $\mathrm{n} 39$, at 184

60 See for example Crawford, above n 47, at 40, n 132; Malcolm N Shaw International Law (6th ed, Cambridge University Press, Cambridge, 2008) at 814; and Ivan Shearer and Brian Opeskin "Nationality and 
a restrictive innovation applicable to sole nationals, Nottebohm has proved to be a ticket good for only one ride.

In addition to diminishing the legal authority of the genuine link doctrine in its original field of operation (as a condition, additional to nationality, on a natural human person's exercise of diplomatic protection) Flegenheimer has, in a related move, served as a common reference point for substantive criticisms of genuine link. It is returned to in that connection in Part III(D) below.

\section{$B$ The Genuine Link in the Context of Plural Nationality}

One of the difficulties one faces in understanding Nottebohm's legacy is that the genuine link requirement has simultaneously proved a dead letter in the context in which the Court applied it (as a restrictive condition on a sole national's ability to bring a diplomatic protection claim) and gained a new lease of life in a different context, that of plural nationality. It did so as an authority for a doctrine which preceded Nottebohm and from which the genuine link requirement was adapted, namely the doctrine of "real and effective nationality". It will be recalled that this doctrine addressed the situation where a person was a national of both the claimant state and the state claimed against. It allowed a claim where the claimant state was, in relative terms, his or her "real and effective nationality".

This repurposed use of Nottebohm has led some to assume that Nottebohm was a case involving a dual national. ${ }^{61}$ Even where scholars are well aware that Nottebohm had only Liechtenstein nationality, the case is nonetheless invoked in the plural nationality context on the grounds that "substantial links in questions of nationality and the exercise of protection" remain relevant in the context of plural nationality. ${ }^{62}$ The critical point is that when used in the context of plural nationality, the use made of the "genuine link" concept differs in key ways from its use in Nottebohm. It no longer serves as a general condition or qualification on a person's nationality, but rather as a means of managing the relationship between the different nationalities held by a person.

The decision treated as initiating this repurposed use of the "genuine link" requirement in the plural nationality context is Mergé, another decision of the Italian-United States Conciliation Commission (along with Flegenheimer), delivered in 1955, only a few months after Nottebohm. ${ }^{63}$ Mrs Mergé was a dual Italian-American national. The Commission held that the United States could

Statelessness" in Brian Opeskin and others Foundations of International Migration Law (Cambridge University Press, Cambridge, 2012) 93 at 97-98.

61 See Dixon, McCorqoudale and Williams who refer to the "circumstances of the case" in Nottebohm as including "where the person was a dual national": see Martin Dixon, Robert McCorquodale and Sarah Williams Cases \& Materials on International Law (6th ed, Oxford University Press, Oxford, 2016) at 436.

62 Weis, above n 39, at 176, and see more generally 176-181. See also Spiro, above n 51, at 61-63.

63 Mergé Claim (Italian-United States Conciliation Commission) (1955) 22 ILR 443. See Weis, above n 39, at 176, and see more generally 176-181. See also Spiro, above 51, at 61-63; and ILC 2006 Report, Yearbook, above n 7, at 34-35. 
not present a claim against Italy on Mrs Mergé's behalf under the Treaty, notwithstanding her undisputed American nationality. The Commission held that, because Mrs Mergé's family did not have its habitual residence in the United States and the "permanent professional life" of the head of the family was elsewhere, she could not be considered "to be dominantly a United States national". ${ }^{4}$

The Commission set up the tension between the doctrine of equality and the doctrine of effective nationality. The Commission treated Nottebohm as resolving the tension between these two doctrines: where the claiming state was the person's predominant state of nationality, the doctrine of equality should yield to the doctrine of effective nationality and the claim be allowed. ${ }^{65}$ Where it was not proved that the claiming state was the predominant state of nationality, the doctrine of equality held, barring the claim. ${ }^{66}$

The above reasoning makes a relative assessment of an individual's strength of connection as between the claimant state and the state claimed against, where the claim is in respect of an individual who is a national of both. In the course of its reasoning, the Commission addressed another scenario. It stated that where a United States citizen possessed the nationality of a third state (ie, other than Italy), this had no bearing on their ability to bring a claim. ${ }^{67}$ Even if the person's predominant nationality was of this third state, this had no effect on his or her ability to bring a claim as a United States' national under the Treaty. This observation underscores the fact that the role assigned to "genuine link" in Mergé was to manage the interaction between nationalities held by a plural national, and not to otherwise qualify a person's nationality or its protections.

This last scenario, where it is argued that because a person's "predominant" nationality was that of a third state they could not rely on another nationality they held as the basis for a claim, has also been rejected in European Union (EU) law. An excursion into EU law is warranted as the relevant legal materials provide a prominent and expressive characterisation of the genuine link requirement as anachronistic. At the centre of the decision of the European Court of Justice (ECJ) in Micheletti is the value of possession of citizenship status, shorn of any additional requirement of "genuine link". 68

Mr Micheletti was a national of both Italy (an EU member state) and Argentina. He was born in Argentina and travelled from there to Spain. He applied, on the basis of his Italian nationality, for a permanent European Community resident's card in Spain in order to practise as a dentist there. Spain denied his application, its rationale being that it was not Italy that was Mr Micheletti's country of

64 Mergé, above n 63, at 456-457.

65 In this article, "dominant" and "predominant" are used interchangeably in the context of the effective nationality doctrine, though see in the text accompanying $n 81$ below.

66 Mergé, above n 63, at 455.

67 At 456

68 Case C-369/90 Mario Vicente Micheletti v Delegación del Gobierno en Cantabria [1992] ECR I-4239. 
"effective nationality", but Argentina. The ECJ rejected this attempt to condition the exercise of his Italian nationality on additional connecting factors. In doing so, it expressly rejected the adoption of Nottebohm's genuine link requirement as a matter of EU law.

The Spanish authorities denied Mr Micheletti's application on the basis of a provision of the Spanish civil code held to provide that in the case of dual nationals, where neither nationality was Spanish, the nationality of a person's prior place of habitual residence (here Argentina) was determinative. The question for the ECJ was: ${ }^{69}$

... may the Kingdom of Spain disregard the status as a Community national of the person concerned,

which derives from his Italian nationality, simply because he possesses Argentinian nationality and

Argentina was previously his country of habitual residence?

The Spanish referring court cited the principle of "effective nationality" from Nottebohm in support of the position of the Spanish authorities, arguing that acceptance of Nottebohm should remove any objection to statutory reliance on "another, subsidiary connecting factor, such as that of habitual residence". ${ }^{70}$ Nottebohm was treated as sanctioning the imposition of additional conditions on recognition of a person's nationality, and habitual residence was treated as a component of the genuine connection test.

Responding to the Nottebohm argument, in his presentation of the case the Advocate General stated: ${ }^{71}$

I do not believe that the case before the Court constitutes an appropriate setting in which to raise the problems relating to effective nationality, whose origins lie in the "romantic period" of international relations and, in particular, in the concept of diplomatic protection; still less, in my view, is the well known (and, it is worth remembering, controversial) Nottebohm judgment of the International Court of Justice of any relevance. Nor, above all, is it necessary, in my opinion, to view the problem in terms of a choice of the applicable law from the standpoint of private international law.

The fact is that Article 52 of the Treaty ... merely requires that at least one of those nationalities, possession of which is not open to question, should be that of a Member State.

The submissions of the Advocate General were followed by the ECJ. ${ }^{72}$ The approach of the ECJ to EU citizenship in Micheletti parallels the approach of the Nottebohm dissents to nationality. The available protections of EU citizenship or public international law are held to hinge on the possession

69 At I-4241-4242.

70 At I-4242. Spain's unsuccessful attempt to employ "effective nationality" here mirrors Italy's unsuccessful invocation of the doctrine in Flegenheimer, above $\mathrm{n}$ 54, as discussed in Part III(A).

71 At I-4255 per Advocate General Tesauro.

72 At I-4263. 
of the relevant nationality. They are not contingent on satisfying any further requirement, whether derived from public or private international law, that a national be a habitual resident. Such additional requirements are dismissed as an anachronism and consigned to the "'romantic period' of international relations". 73

\section{The International Law Commission's Draft Articles}

These two strands of Nottebohm's legacy, a short strand, cut off by Flegenheimer in 1958 with respect to individuals with a sole nationality, and a much longer strand, beginning with Mergé, managing the interaction between states where a person is a national of both, come together in the International Law Commission's Draft Articles on Diplomatic Protection (Draft Articles). ${ }^{74}$ The status of the Draft Articles is not settled. They have been held to represent customary international law in certain respects, ${ }^{75}$ and more generally to have made a substantial contribution to the law of diplomatic protection. $^{76}$

Draft Article 4 states: $:^{77}$

For the purposes of the diplomatic protection of a natural person, a State of nationality means a State whose nationality that person has acquired, in accordance with the law of that State, by birth, descent, naturalization, succession of States or in any other manner, not inconsistent with international law.

In its commentary, the International Law Commission (ILC) states: ${ }^{78}$

Draft article 4 does not require a State to prove an effective or genuine link between itself and its national, along the lines suggested in the Nottebohm case, as an additional factor for the exercise of diplomatic protection ...

The Commission here cited Flegenheimer for the proposition that Nottebohm was limited to the facts of the case in question. ${ }^{79}$

73 At I-4255.

74 ILC 2006 Report, Yearbook, above n 7, at [49].

75 Diallo (Preliminary Objections), above n 7, at 599.

76 See the discussion of the Draft Articles in United Nations General Assembly "Sixth Committee (Legal) - 68th session: Diplomatic Protection (Agenda item 82)" General Assembly of the United Nations <www.un.org/en/ga/>.

77 ILC 2006 Report, Yearbook, above n 7, at [49], art 4.

78 At [50], commentary to art 4, (5).

79 At [50], commentary to art 4, (5). 
The ILC also endorsed the Mergé line of authority. Draft Article 7 states in part: ${ }^{80}$

A State of nationality may not exercise diplomatic protection in respect of a person against a State of

which that person is also a national unless the nationality of the former State is predominant ...

The ILC sourced the term "predominant" in the Mergé claim, and favoured it over the terms "effective" or "dominant" as it "conveys the elements of relativity and indicates that the individual has stronger ties with one State rather than another". ${ }^{81}$ In outlining the jurisprudence on the "effective nationality" doctrine, the ILC notes that Nottebohm relied on, and so supported, this doctrine, which was then given "explicit approval" in Mergé. ${ }^{82}$

In summary, within public international law and with respect to natural human persons, the "restrictive innovation" of Nottebohm has proved to be a "one-off" ${ }^{83}$ The genuine connection test as formulated and applied in Nottebohm, namely as a condition for the recognition of a sole national's nationality status for the purposes of diplomatic protection, can be confined to the facts of the case. In a distinct application, Nottebohm has given impetus to the "real and effective nationality" doctrine that preceded that decision. As outlined above, ${ }^{84}$ the doctrine of real and effective nationality, operating in the context of plural nationality, diverges from the "genuine connection" test in its intent and effects.

To this point in Part III, I have addressed the nature and extent of continuing legal authority for the genuine link principle introduced in Nottebohm. I now turn to substantive lines of criticism of the principle contained in its initial legal reception: in the dissents and decisions and commentary in the five or so years after the decision.

\section{Early Criticisms of the Genuine Link}

Criticisms in Flegenheimer of the genuine connection test have recurred through legal commentary and treatment of the genuine link. In Flegenheimer, ${ }^{85}$ following a discussion of the utility

80 At [49], art 7.

81 At [50], commentary to art 7, (4).

82 At [50], commentary to art 7, (3). In another article, Draft Article 6, the ILC also endorsed the proposition advanced in Mergé that any state of which a person is national is entitled to bring a claim against a state of which that person is not a national; in other words, there is no requirement that the claimant state be the state of predominant nationality in these circumstances.

83 See the references listed above, n 60.

84 In Parts II(B) and III(B).

85 Introduced in Part III(A). 
of "effective nationality" for managing relations between two states in circumstances where a person is a national of both, the Commission continues: ${ }^{86}$

But when a person is vested with only one nationality... the theory of effective nationality cannot be applied without the risk of causing confusion. It lacks a sufficiently positive basis to be applied to a nationality which finds support in a state law. There does not in fact exist any criterion of proven effectiveness for disclosing the effectiveness of a bond with a political collectivity, and the persons by the thousands who, because of the facility of travel in the modern world, possess the positive legal nationality of a State, but live in foreign States where they are domiciled and where their family and business center is located, would be exposed to non-recognition, at the international level ... if this doctrine were to be generalized.

Here, there is a concern that the genuine link requirement will be "generalised", that is, applied outside the plural nationality context introduced in Part II(B) and instead used in the manner in which it was applied in Nottebohm, and a desire to shut down that possibility.

The territorial orientation of "genuine link" is clear from its presentation and use in the majority judgment in Nottebohm. A first substantive objection contained in the quoted passage from Flegenheimer is the apprehension, widespread among early commentators on Nottebohm, that "genuine link" would be Procrustean in its operation, lopping various portions of the citizenry off from the population, in particular expatriates. ${ }^{87}$ The apprehension is that in its application the "genuine link" would denude a person who lived outside his or her state of nationality of protections integral to citizenship status.

In addition to the above apprehensions about the implications of the genuine link for expatriates, the early legal materials raised a more general objection to the principle. The problem identified was the imposition of a general, universal requirement on the messy, and extensive, diversity of principles governing the attribution of nationality worldwide. As stated by Jones: "Whatever these criteria [used to give content to the genuine link] may be they must certainly result in the creation of fresh, and potentially large, classes of unprotected persons. ${ }^{88}$ The genuine link requirement would deprive a

86 Flegenheimer, above n 54, at 150. See also Nottebohm, above n 3, at 55-56 per Judge Guggenheim dissenting. For quotation of the passage see for example: Weis, above n 39, at 184; and Alfred M Boll Multiple Nationality and International Law (Martinus Nijhoff Publishers, Leiden, 2007) at 111. Compare with the highly critical account of both Flegenheimer (including the quoted passage) and Nottebohm provided by Goldschmidt, above n 43, at 707-708.

87 See Nottebohm, above n 3, at 44 per Judge Read dissenting. See also Jones, above n 9, at 239-240.

88 Jones, above n 9, at 244. 
person of the protections of citizenship status when his or her connections to the state did not meet the prescribed content given to the standard. ${ }^{89}$

The above quote from Flegenheimer also raises the difficulty of formulating the "effectiveness" of the relationship, namely "a bond with a political collectivity", as a legal criterion. To adopt the language of Judge Read's dissent in Nottebohm, the introduction of the genuine link requirement threatens to substitute a "vague and subjective test" for "objective tests, readily established, for the existence and recognition of the status". 90 In addition to legal title to citizenship, settled by positive domestic law, the "genuine link" test requires that a person's factual circumstances meet an evaluative standard going to the strength of a person's ties and commitment to his or her country of nationality. The potential issues generated by a "vague and subjective test" go beyond issues of "workability", to the difficulties such tests pose for legal accountability and security of status.

Another way of expressing these apprehensions about making core attributes of nationality dependent on a further factual inquiry has been to point out that the genuine link requirement destabilised and undermined citizenship status as a matter of positive law. The majority reasoning leaves uncertainty as to Nottebohm's legal status beyond Liechtenstein's borders. As complained by an early critic of the decision: ${ }^{91}$

... the posture of his international status remains hopelessly vague. Liechtenstein proclaims him a national.

Guatemala discounts that claim, stating that he is a German ... The Federal Republic of Germany expressly refutes any relationship with Nottebohm ... The result is that Friedrich Nottebohm's status is fixed and determinable only within the geographic configuration of Liechtenstein, a sovereign Principality having the same area as the District of Columbia.

In denying recognition to Nottebohm's nationality for the purposes of Liechtenstein's diplomatic protection claim, the Court cast doubt over his nationality status more generally. ${ }^{92}$

89 Criticisms of the genuine link requirement as developed and employed in Nottebohm are distinct from the broader question of whether international law can and/or should deny recognition on other grounds to citizenship validly conferred under domestic law, for example on the grounds that the domestic law is racially discriminatory. On the latter ground see for example Peter J Spiro "A New International Law of Citizenship" (2011) 105 AJIL 694 at 722.

90 Nottebohm, above n 3, at 46 per Judge Read dissenting. For a discussion situating these issues in a contemporary factual context see Rishi Gulati "The relevance of nationality in the age of Google, Skype and Facebook" in Fiona Jenkins, Mark Nolan and Kim Rubenstein Allegiance and Identity in a Globalised World (Cambridge University Press, Cambridge, 2014) 542 at 558-560.

91 Jack H Glazer "Affaire Nottebohm (Liechtenstein v Guatemala) - A Critique" (1956) 44 Geo LJ 313 at 322 323

92 The Nottebohm majority held that denying recognition to Liechtenstein's conferral of citizenship left his domestic citizenship status unaffected and stated "nationality has its most immediate, its most far-reaching and, for most people, its only effects within the legal system of the State conferring it": Nottebohm, above n 
Finally, there is the question of who gains in power from making a person's ability to access the protections of citizenship dependent on an additional factual inquiry. The factual assessment of whether a person's relationship to his or her state of nationality is characterised by "sincerity, fidelity, durability, lack of substantial connection", or whatever evaluative criteria are used to give content to the "genuine link" principle, is an assessment that will be carried out by state officials. ${ }^{93}$ "Vague and subjective tests" point to a significant increase in discretion and power for the officials charged with determining whether the relevant criteria are met. ${ }^{94}$

Notwithstanding the genuine link's diminished, or at least decentred (to the plural nationality context), place in public international law $^{95}$ and its critical reception in that discipline, ${ }^{96}$ the test continues to be invoked in political and theoretical discussion. Its usage in these fields both draws on and expands the conditional approach to nationality endorsed in Nottebohm. This usage is the subject of the next Part.

\section{USE OF THE "GENUINE LINK" REQUIREMENT IN CITIZENSHIP THEORY}

\section{A Shachar's Use of The Genuine Link}

The "genuine link" requirement has proved influential in citizenship theory. I analyse a prominent work of political theory that draws heavily on Nottebohm and the genuine link requirement, Ayelet Shachar's The Birthright Lottery. ${ }^{97}$ Her account makes readily apparent how the "genuine link" requirement can be seen to inspire a progressive and inclusionary account of citizenship. Conversely, it also demonstrates what one has to forget and misconstrue about Nottebohm to have the decision serve this purpose. Shachar's proposal is a work of normative political theory. Issues with the nature

3 , at 20. This attempt by the majority to downplay the transnational dimension of citizenship is incongruous in the circumstances of the case, as conveyed by the quote from Glazer in the text.

93 Nottebohm, above n 3, at 46 per Judge Read dissenting.

94 A municipal law analogy to illustrate the power conferred by "vague and subjective" conditions on citizenship can be found in the British deprivation power introduced in 2006 whereby a British citizen can be stripped of that status if the Secretary of State is "satisfied" that this is "conducive to the public good": British Nationality Act 1981 (UK), s 40(2). A closer analogy with the genuine link requirement, because they are still framed in terms of a connection between citizen and state rather than as an open-ended discretion, are Australian citizenship deprivation powers, introduced in December 2015, that are triggered by an Australian engaging in conduct "inconsistent with their allegiance" to Australia: see Australian Citizenship Act 2007 (Cth), s 33AA(1). On the "substantive, multidimensional" concept of allegiance relied on to support the constitutionality of the Australian Act see Helen Irving and Rayner Thwaites "Australian Citizenship Amendment (Allegiance to Australia) Bill 2015 (Cth)" (2015) 26 PLR 137 at 145.

95 As discussed in Part III(A)-(C).

96 As discussed in Part III(D).

97 Shachar, above n 2 . 
and operation of the criterion in law and the criticisms contained in the legal materials might not affect the strength of her normative argument. I argue that they do.

The Birthright Lottery is centrally concerned with global distributive justice and the structural inequality that results from the allocation of citizenship by birth. Being born with Canadian citizenship, for example, greatly improves one's life chances and opportunities relative to being born, for example, a Syrian citizen. Shachar argues that we should conceptualise citizenship status as a form of property. Acquisition of citizenship by birth raises issues of distributive justice familiar from debates over inheritance of property. To address these distributive inequities, Shachar advocates a birthright privilege levy on those born with a favoured citizenship.

In the final chapter of her book Shachar proposes a reform to citizenship acquisition. The reform seeks to remedy problems of under- and over-inclusion in a state's distribution of membership. Underand over-inclusion are judged relative to the desiderata that citizenship status should track a person's ties to a given state. ${ }^{98}$ "Resident stakeholders" in a state should be entitled to full membership; conversely, full membership should not be extended to those with only a nominal connection to the state. $^{99}$ To achieve this objective, Shachar proposes to substitute what she calls a "jus nexi" requirement for those imperfect proxies for "genuine connection": citizenship by birth (jus soli) and by descent (jus sanguinis). In developing and elaborating this "genuine connection principle of membership acquisition" she draws heavily on Nottebohm. My comments on Shachar's work are directed not to her broader argument on the relationship between citizenship and global distributive injustice, but to the use she makes of her "genuine connection principle of membership acquisition". 100

Her jus nexi requirement is derived, in part, from her reading of the legal materials. She states: ${ }^{101}$

In outlining the jus nexi membership criterion, I draw upon the growing acceptance of the genuine-

connection criterion in court decisions, regulatory regimes, and academic commentaries on the place of

residence and the relevance of factual membership and actual ties to the polity.

Shachar's claim for the criterion's "growing acceptance" in court decisions and regulatory regimes is overstated and in need of clarification and qualification. ${ }^{102}$ Shachar may appear to be using "genuine connection" loosely. There are ambiguities in her account as to: whether the genuine connection principle is to function as a legal criterion or as a general policy preference; whether

98 At 165 .

99 At 165.

100 At 164

101 At 165 .

102 See Part III. 
"citizenship" is to be understood in the extra-legal sense of social inclusion or as a legal status; and whether "genuine link" would be used to create legal status or as a basis for legal entitlements. It remains the case that Nottebohm is central to her exposition of her jus nexi principle. She is uncritical of the decision. She introduces Nottebohm stating: ${ }^{103}$

The idea of adopting a functional, genuine connection criterion for defining citizenship finds support from an unexpected source: the jurisprudence of international law. In the ... Nottebohm decision, the [ICJ] held that citizenship is not merely an empty "title".

She then quotes the passage encapsulating the genuine link requirement, quoted in the Introduction. ${ }^{104}$ She approves the criterion's application in Nottebohm on the basis that it led the ICJ to "'pierce the veil' of membership title in the search for that something else that makes citizenship effective at the international law level vis-à-vis another polity". ${ }^{105}$ And she returns to Nottebohm to "illuminat[e] ... the meaning to be given to the genuine-connection conception of membership", the "subject matter" of her inquiry. 106

Shachar's use of the genuine link requirement differs in certain basic respects from its usage in Nottebohm. Shachar introduces jus nexi as a "genuine-connection principle of citizenship acquisition". ${ }^{107}$ Her theory is not addressed to diplomatic protection or to other consequences of nationality at international law, but to the principles of citizenship acquisition as a matter of municipal law. ${ }^{108}$ A further feature of Shachar's account is that she presents the genuine link principle as

103 Shachar, above n 2, at 166

104 See in the text accompanying n 6 above.

105 Shachar, above n 2, at 167.

106 At 168

107 At 164

108 This is an application of the genuine link concept that has also been employed in political discussions of citizenship status: see for example Viviane Reding, Vice President of the EU Commission and EU Justice Commissioner "Citizenship must not be up for sale" (speech to the Plenary Session debate of the European Parliament on "EU citizenship for sale", 15 January 2014). In condemning the implications for EU citizenship of a Maltese proposal to sell Maltese citizenship (Malta being an EU member state), Reding said "Member States should only award citizenship to persons where there is a 'genuine link' or 'genuine connection' to the country in question". This was framed as a political warning as distinct from a proposal for conferral of legal competence: "While I am not calling for the Commission to receive legal power to determine what constitutes nationality or the rules granting it, the Commission nevertheless expects that Member states act in full awareness of the consequences of their decisions." In its political register, proceeding from the proposal's perceived consequences for other states, the EU Commissioner's reaction is akin to Canada introducing a visa requirement for travel to Canada by citizens of St Kitts and Nevis in response to concerns over that country's provisions for sale of citizenship: see Government of Canada "Archived - Notice - St Kitts and Nevis citizens now need a visa to travel to Canada" (22 November 2014) <www.canada.ca>. 
potentially in and of itself sufficient for the grant of citizenship. ${ }^{109}$ Her jus nexi principle of membership allocation is effectively proposed as a substitute for the classic modes of citizenship acquisition: by birth (jus soli) and by descent (jus sanguinis). Shachar leaves it open as to whether jus nexi is a "complete alternative to jus soli and jus sanguinis or ... a supplementary principle for membership acquisition". ${ }^{110} \mathrm{In}$ its former guise, Shachar's proposal is akin to requiring some form of naturalisation process for all citizens. ${ }^{111}$ In its latter, supplementary, formulation, it is much closer to the current status quo in many countries in which modified forms of jus soli and jus sanguinis now apply. ${ }^{112}$

An additional complication in Shachar's use of the "genuine link" is that she does not clarify what entitlements are held to be core attributes of citizenship, understood as a legal status. The legal reception and treatment of Nottebohm proceeded from the understanding that diplomatic protection was an integral feature of nationality, such that denying recognition to a person's nationality for the purpose of diplomatic protection challenged existing understandings of nationality as a legal status. By way of contrast, cases which require, for example, habitual residence in addition to citizenship in order to be eligible for a welfare benefit are analytically distinct. In such cases, the issue is that citizenship is a necessary, but not sufficient, condition for a particular benefit. Unless the particular benefit is held to be a core attribute of citizenship, the grant or withholding of the benefit does not challenge our understanding of citizenship in the way that denying recognition to Nottebohm's citizenship did. Shachar treats both categories of case as speaking to the "genuine connection principle of membership acquisition". 113

Shachar's reasons for making the genuine link principle central to her account highlight some of its perennial attractions. When employed as a concept of citizenship acquisition the genuine link requirement can serve an integrative function. ${ }^{114}$ Where a person makes his or her life in a particular country the jus nexi concept provides a direct basis for integration into the citizenry of the state in which they find themselves, should he or she wish to take up that citizenship. ${ }^{115}$ The concept promises

109 If the majority in Nottebohm had applied "genuine link" in this way, it would have led to the conclusion that Friedrich Nottebohm was a Guatemalan national.

110 Shachar, above $\mathrm{n} 2$, at 165, 179-180 and 188.

111 At 180-181, where the analogy with naturalisation is made explicit, and see in particular at 181, n 57.

112 See for example the use Shachar makes of practices in the United States and Canada on restrictions on the transmission of citizenship status for overseas citizens: Shachar, above n 2, at 174 and 180 respectively.

113 See for example Shachar's treatment of Case C-138/02 Brian Francis Collins v Secretary of State for Work and Pensions [2005] ECR I-02703 in Shachar, above n 2, at 176.

114 See for example at 180 .

115 Shachar makes clear that, supposing someone is eligible for a citizenship under her jus nexi principle, whether or not the person takes up that citizenship is a matter for him or her: Shachar, above n 2, at 179. 
to dissolve arbitrary distinctions between those who live together, distinctions based on citizenship status.

Having said that Shachar's account is integrative, it is integrative in a particular way. The citizenship status follows the social facts. Shachar does not consider the reverse possibility, whereby citizenship status is granted in anticipation of the development of "a social fact of attachment" to the state, the status serving as a promise of stability, so enabling such integration.

\section{B The Dynamics of the Genuine Link}

The danger that corresponds to the integrative virtues of the genuine link is that the concept threatens to deformalise citizenship status. The central point that Shachar wants us to take from Nottebohm is: ${ }^{116}$

... that instead of relying on mere formal status of affiliation, the more important criterion is to examine the social fact of attachment, the genuine connection of a person to the polity as a valid and relevant basis for citizenship allocation.

For Shachar, the genuine link principle expresses the relationship between citizen and state to which citizenship status should aspire. This leads to her proposal to directly instantiate the desired relationship in law as a principle of citizenship acquisition. As with the Nottebohm majority, she does not consider the negative consequences of trying to directly instantiate the desired relationship in legal criteria.

Shachar's jus nexi principle is directed at reducing arbitrariness, understood as a lack of correlation between a person's lived experience and commitments and the nationality that he or she holds. ${ }^{117}$ Citizenship is an ascriptive status, ascribed to citizens by governments. The drive to align citizenship status with "a social fact of attachment" can be seen to support the integration of permanent residents into the polity. It can also be seen to support a conditional model of citizenship, according to which only those citizens who can satisfy the requisite "social fact of attachment" benefit from the

116 At 167. Shachar situates her work as part of a more general wave of scholarship influenced by relational theory that champions "an actual, real, everyday and meaningful web of relations and human interaction", set against "static, blanket formalism": see at 167-168. One can value relational theory, while questioning the appropriateness of its application to the highly asymmetric power relation between citizen and state found in citizenship and nationality law. For an account questioning the application of relational theory to administrative law in these terms see Robert Leckey Contextual Subjects: Family, State, and Relational Theory (University of Toronto Press, Toronto, 2008).

117 Shachar does not consider the possibility that the arbitrariness of birthright citizenship might be, in its own way, inclusionary. Certainly, moves to qualify pure jus soli in the United Kingdom, Australia and elsewhere have been exclusionary in intent and effect: see for example Ann Dummett and Andrew Nicol Subjects, Citizens, Aliens and Others: Nationality and Immigration Law (Weidenfeld and Nicolson, London, 1990) at 244-246. Here, compared to Shachar, there is the possibility of citizenship first, with integration to follow. 
protections of the status. Of the two alternatives, this second, conditional, dynamic is the one that more accurately characterises the Nottebohm decision.

A conditional approach to citizenship is suggested by Shachar's emphasis on her jus nexi proposal as "a conception of membership that emphasizes mutual responsibility and actual ties as the basis for claiming access to and participation in, the community's membership boundaries and democratic decision-making processes". ${ }^{118}$ If mutual responsibility means that citizenship or rights integral to that status (centrally diplomatic protection and a person's right to enter and remain in his or her country of nationality) are contingent on a citizen meeting certain obligations or requirements, then it has considerable potential to destabilise the securities of citizenship status. ${ }^{119}$

Shachar returns to Nottebohm to "illuminate the meaning to be given to the genuine connection conception of membership". ${ }^{120}$ Problems with the content Nottebohm gave to the "genuine link" requirement, outlined in the discussion of early authorities and commentary on Nottebohm in Part III, are replicated in Shachar's jus nexi proposal. These include: "a crucial role" for "prolonged residence"; 121 a lack of guidance as to what constitutes a "genuine connection" in the absence of that territorial connection; ${ }^{122}$ and in part as a result of these first two features, a decidedly awkward fit between the genuine connection test and multiple citizenship. ${ }^{123}$

Rejecting Shachar's jus nexi or other principles derived from the "genuine link" does not preclude citizenship law reform in an inclusionary direction. The criterion's use as a legal condition can be contrasted with "a social fact of attachment" informing policy on citizenship status. A general residency requirement for naturalisation, ${ }^{124}$ or limits on the intergenerational transmission of

118 Ayelet Shachar "The Future of National Citizenship: Going, going, gone?" (2009) 59 UTLJ 579 at 586, n 11 See also Shachar's emphasis on the "implied notion of reciprocity and joint responsibility that informs the reliance on a genuine link test for distributing membership": Shachar, above n 2, at 184.

119 For a critical response to the view that rights should be "paired" or "balanced" with responsibilities, framed as a response to Rights and Responsibilities: Developing our Constitutional Framework (United Kingdom Ministry of Justice, Green Paper, March 2009), see Pavlos Eleftheriadis "On rights and responsibilities" [2010] PL 33.

120 Shachar, above $\mathrm{n} 2$ at 168.

121 At 178

122 Shachar disclaims making territorial presence "the all or nothing criterion": at 179. Her positive account of what criteria might supplement, or possibly substitute for, territorial presence is limited, relying on the "centre of interests" test from Nottebohm, quoted in the text accompanying n 52 above.

123 In a short paragraph Shachar does affirm multiple citizenship: at 179. In this passage Shachar appears to reference the distinct use made of Nottebohm in the plural nationality context, discussed in the text above in Part III(B). She does not directly address the evident hostility of the genuine connection test, as elaborated and employed in Nottebohm itself, to multiple citizenship.

124 Provided this is not treated as an inflexible requirement without exceptions. 
citizenship with respect to citizens who have relocated to another country both implement a policy preference that citizenship should, to some degree, correlate with a citizen being a "resident stakeholder". Legislative provisions implementing these policies can avoid the problems that are raised by the genuine link requirement. They need not invite the prospect that a person's citizenship status will be impugned on the grounds that his or her citizenship is not "genuine", or that a person's entitlement to exercise the core attributes or protections of citizenship status will depend on an assessment of whether a person has a "genuine link" to the polity.

\section{CONCLUSION}

On the plane of international law, recognition of citizenship validly acquired under municipal law and of the core attributes of that status should not depend on a finding of "genuine link". As outlined in Part III, this is already the position under international law. International law has distanced itself from the general link doctrine employed in Nottebohm. ${ }^{125}$ The criticisms of the principle contained in the legal materials are manifold: ${ }^{126}$ the territorial orientation of the test threatened the legal protections of expatriates and the institution of multiple nationality; the use of an evaluative test undermines legal certainty and so legal protections; the more content that is given to the test, the more people will be left unprotected; and a requirement that a person's relationship to the polity is one of "sincerity, fidelity, durability ... [or] substantial connection"127 enhances the power of the officials charged with determining if the requirement is met. The common thread is that conditioning citizenship status or its core attributes on substantive connections, deformalising it, makes it less stable and more vulnerable, and its protections more precarious.

The genuine link principle gives expression to a powerful idea, that the protections that attend a person's nationality status are predicated on a "social fact of attachment, a genuine connection of existence, interests and sentiments" to the relevant state. In introducing this principle, Nottebohm introduced a "restrictive innovation" that arguably did an injustice to the litigant in that case. A return to Nottebohm and its legacy focuses attention on the dissonance between hopes that citizenship status will correlate with an underlying social solidarity, for which the genuine link has served as an inspiration, and issues generated by attempting to instantiate those ideals in law as a legal criterion.

125 See Parts III(A)-(C).

126 See Part III(D).

127 Nottebohm, above n 3, at 46 per Judge Read dissenting. 